\title{
Collaborative Learning in the teaching of Usul Fiqh (Islamic Jurisprudence) at the Pre-University Level in Brunei Darussalam
}

\author{
Gamal Abdul Nasir Zakaria \\ Sultan Hassanal Bolkiah Institute of Education, Universiti Brunei Darussalam \\ Email: gamal.zakaria@ubd.edu.bn \\ Salwa Mahalle \\ Sultan Hassanal Bolkiah Institute of Education, Universiti Brunei Darussalam \\ Email: salwamahalle@gmail.com \\ Zeti Abu Bakar \\ Sultan Hassanal Bolkiah Institute of Education, Meragang Form Sixth Center \\ Muara - Tutong Highway, Brunei \\ Aliff Nawi \\ Sultan Hassanal Bolkiah Institute of Education, Universiti Brunei Darussalam \\ Email: aliffnawi@yahoo.com
}

Doi:10.5901/mjss.2015.v6n3s1p158

\section{Abstract}

This research was conducted to analyse the effectiveness of Collaborative technique in the teaching and learning of Usul Fiqh (UF). The main aim of this study was to find out the differences in achievement levels of the experimented groups that had been taught using the Collaborative technique and the achievement levels of the controlled group (taught using the conventional approach). Also, this study aimed to analyse the attitudes of students towards the learning of UF; before and after the intervention, the views and perceptions of the students towards collaborative technique as well as the problem faced during the collaborative intervention. The study used quasi-experimental method of research by applying post-test design. A total of 42 students from one of the Form Six centres in Brunei was chosen. The analysis showed that there was significant difference between the two groups whereby the experimented group achieved significantly higher results compared to controlled group. Furthermore, this study also show the attitude of the students towards the learning of UF after the induction of the Collaborative technique was not much different when compared to their attitudes before Collaborative was introduced. Finally, analysis of data showed that the students had slight problems in following the learning of UF using Collaborative Approach, with mean value of 3.51 .

Keywords: Collaborative techniques, experimental,secondary school, Brunei

\section{Introduction}

The education system in Brunei Darussalam has experienced a transformation in order to meet the objectives set in the nation's vision 2035. Among the objectives are to provide educated people, highly skilled and able to bring the education system to a world class level. In line with this, it is therefore very important to produce quality teachers because the teachers are the ones who will educate and structure the new generation through the knowledge given. Teachers can be considered as the changing agents who are given the responsibilities to make the nation's aspirations and vision to reality.

In the speech of His Majesty, Sultan and Yang Dipertuan, in commemorating the 21st celebration for Teachers' Day, he mentioned that in any situation, teachers are expected to bring changes, from being illiterate to literate as well as from 'not knowledgeable' to someone with knowledge. In terms of education, it is obvious that the learning process should be conducive with complete facilities provided in order for the students to think actively, able to work with others, with principles and self-learning. According to Tan (2004), the pedagogy today is to give opportunity to students to the 
way of 'thinking visible'.

\section{Statement of Problem}

Usul Fiqh or Islamic Jurisprudence is one of the subjects offered in the Sixth Form Centres in Brunei Darussalam. It is a popular subject among the students because from year to year, there is an increase in enrolment, for instance in 2009, there were 406 students enrolled in this subject; in 2010 there were 330 students and in 2011, there were 459 takers. Although the percentages of takers increases but still the number of passers is still at the unsatisfactory level (See Table 1).

Table 1. Students' achievement in the subject of Syari'ah for BGCE A'Level

\begin{tabular}{|lcccc|}
\hline Year & Students enrolled & Grade A-C (\%) & Grade D-E (\%) & Failures (\%) \\
\hline 2007 & 401 & 60.85 & 31.17 & 7.98 \\
2008 & 398 & 56.53 & 33.67 & 9.8 \\
2009 & 406 & 69.95 & 21.68 & 8.37 \\
2010 & 330 & 60.9 & 28.8 & 10.3 \\
2011 & 459 & 58.82 & 28.54 & 12.63 \\
\hline
\end{tabular}

Source: Department of Examination, Ministry of Education, Brunei (2012)

From the table, it can be seen that the percentages of students getting grades $D$ and $E$ increased from 2009 to 2011 and the number of failures too, are in the high range. According to Hassan Langgulung (1981), one of the pedagogical aspects which need to be looked into is the teaching-learning approach. Application of various teaching methods and activities may produce effective teaching strategies. This is supported by Juriah (1990) and Nawi and Ramlan (2014) where among reasons why students are demotivated in class is due to the teaching patterns of the teachers which are boring and not creative.

In relation to this, according to Rose Dee (2009), most of the teachers in Brunei Darussalam who are teaching Syari'ah, the popular approaches used in their lessons are lecture, talk and verbal explanation only. This implies that most of the teachers prefer to use the conventional way of teaching. Hence, this study is aimed to investigate the effectiveness of using Collaborative Approach in teaching which is simultaneously parallel to the needs of SPN21.

\section{Conceptual Framework}

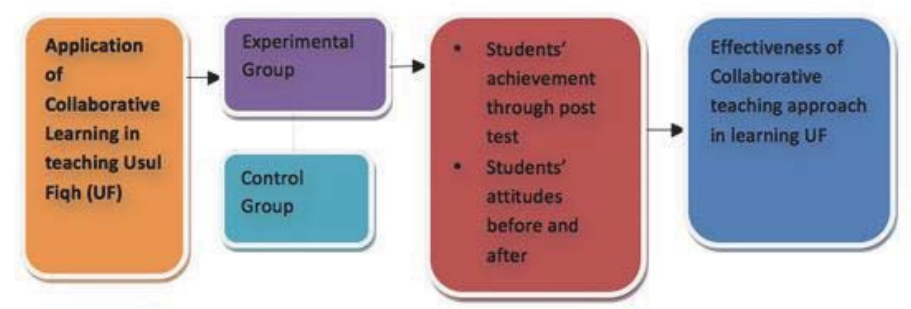

Figure 1. Research Conceptual Framework

The conceptual framework shows that the Collaborative Learning is applied on the experimental group. As a result, from the treatment given, comparison is done in terms of students' achievement in the experimental group before and after treatment as well as the achievement of the students in the control group (taught using the conventional approach) are observed through the post-test given.

\section{Research Objectives}

This research is underpinned by the following objectives, namely: 
- To identify the effectiveness of Collaborative Approach in students' achievement compared to Conventional Approach ;

- To identify the effectiveness of Collaborative Approach with regard to students' attitudes compared to the Conventional Approach;

- To assess students' perception towards the usage of Collaborative Approach in teaching Usul Figh (UF); and

- To identify the problems faced by students towards the application of Collaborative Approach in teaching UF.

\section{Research Methods}

This study is a quasi-experimental study which aims to look at the effectiveness of Collaborative Learning in teaching UF for the pre-university students. Samples involved were students who have been identified earlier whereby according to Wiersma (1995), when intact group of subjects are used in an experiment, it is called as quasi-experiment.

Two classes were involved where the students were divided into two groups, A \& B. Students in Group A were given treatment, where Collaborative Learning was used in their lessons, whereby, Group B was not given any treatment, that is, teacher used conventional approach in the lessons. Written test was also used to assess the effectiveness of both approaches used.

This study used two instruments namely written test and questionnaire. The written test was used as post-test (given after treatment). The test was given 6 weeks after treatment and a topic in the syllabus was selected. In this case, students in Group A were given the treatment and after 6 weeks they were given a written test to see the effectiveness of Collaborative Learning in their lessons. Effectiveness can be seen from the scores obtained in the test.

In the written test, 4 questions were given where students were asked to answer 3 out of 4 . Each question carries 20 marks. Marking scheme was based on the standards set for the BGCE A'Level exam. Questionnaire was used because of its practicality and it allows respondents to give their feedbacks. The items in the questionnaire are also used to identify students' perceptions towards the practice of Collaborative Learning.

This study involved 42 pre-university students and they were divided into two groups, as mentioned earlier (21 students for each group). Respondents are assumed to have different level of academic achievement.

Table 2. Respondents of the study

\begin{tabular}{|ccc|ccc|}
\hline \multicolumn{3}{|c|}{ Group A } & \multicolumn{3}{|c|}{ Group B } \\
\hline Male & Female & Total & Male & Female & Total \\
6 & 15 & 21 & 6 & 15 & 21 \\
\hline
\end{tabular}

\section{Results}

\subsection{Significant Difference Between the Collaborative Approach \& Conventional Approach In Terms Of Students' Achievement in Learning Usul Fiqh}

Results showed that there is a significant difference between the 2 groups (Group A \& B) whereby the mean values for Group A is 39.4 and Group B is 22.4. This indicates that students in Group A performed better and have higher marks compared to students in Group B.

Table 3. Mean, Standard Deviation and t-test for Students' achievement in Post test

\begin{tabular}{|lccccc|}
\hline Group & $\mathrm{N}(\mathrm{f})$ & Mean & S.D & t value & $\mathrm{P}<0.05$ \\
\hline Experiment $(\mathrm{A})$ & 21 & 39.4 & 10.73 & 4.30 & 0.00 \\
Control $(\mathrm{B})$ & 21 & 22.4 & 11.81 & & \\
\hline
\end{tabular}

S.D = Standart Deviation

\subsection{Significant Difference In Students' Attitude In Learning Usul Fiqh Before \& After Treatment}

Data shows that there is a significant difference in students attitudes $(p<0.00)$, that is, the students' attitudes when given conventional treatment shows a higher value compared to students who were given the treatment of Collaborative Learning. There is also a reduction in the mean values before and after treatment, that is, before treatment was given, 
mean value was 3.20 and after treatment, mean value $=3.24$.

Table 4. Mean, Standard Deviation and t-test for students' attitudes before and after treatment

\begin{tabular}{lccccc}
\hline Group & $\mathrm{N}(\mathrm{f})$ & Mean & S.D & t value & $\mathrm{P}<0.05$ \\
\hline Experiment $(\mathrm{A})$ & 21 & 3.30 & 0.39 & 38.72 & 0.00 \\
Control (B) & 21 & 3.24 & 0.45 & 32.58 & \\
\hline
\end{tabular}

S.D = Standart Deviation

\subsection{Students' Perceptions Towards The Application of Collaborative Approach In Learning Usul Fiqh}

Data was analysed descriptively and it was found that overall, the students have positive perceptions towards Collaborative Approach with a mean value of 3.76 (see table 5). Their perceptions are divided into 4 aspects namely attitude, knowledge, skills and value, and learning. From the table, the knowledge dimension (see table 6) shows the highest mean value (mean $=3.96$ ), followed by skills and values (mean $=3.86$ ). For conclusion, students agreed that Collaborative Approach is able to improve their understanding and their memorization skills especially in learning Usul Fiqh and they too recommended that this approach be taught and applied to students at secondary levels for all subjects taught.

Table 5. Mean values for Students' perceptions (Attitude, Knowledge, Skills and Values, Learning) towards the usage of Collaborative Approach

\begin{tabular}{ccc}
\hline Perceptions & Mean Values & Standart Deviation \\
\hline Attitute & 3.56 & 0.87 \\
Knowledge & 3.96 & 0.71 \\
Skills and Values & 3.86 & 0.48 \\
Learning & 3.66 & 0.69 \\
\hline Total & 3.76 & 0.56 \\
\hline
\end{tabular}

Table 6. Percentages regarding the knowledge of students on Collaborative Approach

\begin{tabular}{|c|c|c|c|c|c|c|}
\hline Items & 1 & 2 & 3 & 4 & 5 & Mean \\
\hline Through CA,I can improve my understanding in learning UF & $\overline{0}$ & $19 \%$ & $4.7 \%$ & $38.1 \%$ & $38.1 \%$ & 3.95 \\
\hline CA challenges my ability and my knowledge & 0 & $4.7 \%$ & $9.5 \%$ & $42.8 \%$ & $42.8 \%$ & 4.24 \\
\hline CA allows me to use my previous experience and knowledge in problem solving & 0 & $4.7 \%$ & $19 \%$ & $52.3 \%$ & $23.8 \%$ & 3.95 \\
\hline Through CA, knowledge and information obtained stay in my memory for a longer period & 0 & $23.8 \%$ & $14.2 \%$ & $23.8 \%$ & $38.1 \%$ & 3.76 \\
\hline Through CA, I gain more new information or knowledge from friends & 0 & $9.5 \$$ & $19 \%$ & $42.8 \%$ & $28.5 \%$ & 3.9 \\
\hline
\end{tabular}

\subsection{Problems Faced by Students During The Application of Collaborative Approach In Teaching Usul Figh}

From Table 7, it can be seen that on the whole, the level of problems faced by the students regarding the usage of Collaborative Approach is at the moderate level (mean = 3.53). It is also found that the highest dimension of problem faced is related to time and nature of tasks, second comes the problem with regard to facilities and dimensions related to 'self, peers and parents' has the lowest mean.

With regard to time and nature of tasks, the students strongly agreed that they are burdened with school tasks of other subjects which made them passive and less creative; having difficulties in organizing time to do discussion with peers or classmates and limited time avail in implementing the Collaborative Approach in learning.

Table 7. Mean Values for Types of Problems faced by students during the implementation of Collaborative Approach

\begin{tabular}{ccc}
\hline Types of Problems & Mean & Standart Deviation \\
\hline Facilities & 3.48 & 0.73 \\
Self, Peers and Parents & 3.11 & 0.77 \\
Time and Tasks & 3.96 & 0.70 \\
Total & 3.53 & 0.46 \\
\hline
\end{tabular}




\section{Discussion}

This study shows that there is a significant difference in students' attitude with regard to learning UF using Collaborative Approach. Nevertheless, the Collaborative Approach is seen by the students as a positive approach whereby, at least this gives an indication that with positive attitudes may result high effort from the students which consequently they will work harder in order to achieve better compared to students with negative attitudes. According to Chooi (1998), effort and interest, if combined may produce good results from the students.

The students too, show positive perception towards Collaborative Approach. This result supports research done by Noraziah (2007), where in the research, the researcher confirmed that Collaborative Approach in learning may result to various types of positive attitude which ultimately produce good academic achievement. Collaborative Approach encourages students to use their existing knowledge in order to solve problems. Apart from that, Collaborative Approach can also motivate students to 'learn how to learn' as well as to be a more efficient and independent students.

Undoubtedly, students do face problems during the application of collaborative Approach in their lessons. Majority of the students agreed that given a chance to overcome these problems, given good teaching materials as well as good facilities, would help them to improve their learning. In addition, factors like peers and parents do give impact on their academic achievement. This study supported a study done by Ching et.al (1990) where majority of the students in that study voiced out the needs of having good teaching materials and facilities for them to get good results. The right circles of friends and role of parents do give great impact on the students' performance (Kamaruddin, 1989; Taha 1981).

\section{Conclusion}

This study proved that cultivating Collaborative Approach in learning UF can aid in increasing students' quality of learning. On the other hand, the conventional approach too, gives good impact on students' learning even though the results may not be as good as when Collaborative Approach is used. Collaborative Approach is also seen suitable and relevant to be used in teaching UF and can help students to be more positive and can help them in their problem based solving skills.

\section{References}

Ching, L.Y., (1990). Faktor-faktor yang mempengaruhi pendapaian akademik pelajar di sekolah-sekolah Malaysia. Tesis Universiti Malaya, Kuala Lumpur

Chooi, Foo Siet., (1998)., Hubungan antara sikap, jantina dan penguasaan konsep asas matematik dengan pencapaian dalam matematik moden untuk pelajar jurusan sastera. Tesis Sarjana. Universiti Kebangsaan Malaysia.

Davidson., (1991). An overview of research on Cooperative Learning related to Mathematic. Journal for research in Mathematic Education.

Forman, E. \& Gazden. C., (1986). Exploring Vygotskian perspectives in Education:The cognitive value of peer interaction. In J.V.Wertsch (Ed.). Culture communication and cognition : Vygotskian Perspectives. New York: Cambridge University Press

Hassan Langgulung., (1997)., Asas-asas pendidikan Islam. Kuala Lumpur: Dewan Bahasa dan Pustaka

Johnson \& Johnson., (1989). Cooperative and competition, Edina: Interaction Book company

Juriah Long., (1998). Inovasi dalam perkaedahan dalam pengajaran Bahasa, Sains Sosial dan Teknolohi Maklumat. Bangi: Penerbit Universiti Kebangsaan Malaysia,Kuala Lumpur

Nawi, M. A. M., \& Ramlan, Y. (2014). A Study on the Strategies and Practice of Teaching Among Trainee Teachers During Teaching Training, The Online Journal of Islamic Education, 2(1): 1-6 http://e-journal.um.edu.my/filebank/published_article/6052/Article_ 1_V2_I1_Jan2014.pdf

Kamarudin Hj Husin., (1989). Psikologi bilik darjah, Asas pedagogi : Kuala Lumpur: Utusan Publication \& Distributors Sdn. Bhd

Nor Azizah Md Salleh., (1997)., Pembelajaran koperatif, Apa, Mengapa dan bagaimana?: Siber Didik, Fakulti Pendidkan, Universiti Kebangsaan Malaysia

Rose De Yusof bin Hj Mohd Ramlee., (2009). Aplikasi pembelajaran aktif untuk mata pelajaran Syariah bagi Peringkat Pra U, Negara Brunei Darussalam. Tesis Sarjana Pendidikan Pengajian Islam, Brunei Darussalam

Taha Abdul Kadir., (1981). Persekitaran rumahtangga dan pencapaian akademik murid-murid di Sekolah Menengah Kebangsaan. Tesis Sarjana, Fakulti Pendidikan,Universiti Malaya

Tan Oon Seng., (2004). Enhancing thinking through Problem Based Learning Approaches. Singapore:Thomson Learning

Tinzman, T.B., (1990). What is collaborative classroom?. NCREL Oakbook

Vygotsky, L.S., (1986). Thought and Language Cambridge. MA: MIT Press

Wiersma,W., (1995). Research methods in Education: An introduction (6th Ed). USA: A Simon and Schuster Company Needham Heights, Massachusetts 02194 